\title{
Did China's Foreign Exchange Policy Hinder the US Recovery from the Global Financial Crisis?
}

\author{
Abhishek Kumar, Wui-Ken Liow, Joanna Moss, Yuan Sun, Zhong Yi Wang \& Xi Zhuang \\ “...substantially undervalued..." \\ - Tim Geithner, US Treasury, January 2011 \\ “...China manipulates its currency..." \\ - Charles Schumer (D), February 2011 \\ “...huge competitive disadvantage..." \\ - President Obama, February 2010
}

The quotes above convey the perception that China's foreign exchange policy has had a harmful impact on the US economy. This paper examines whether China's foreign exchange policy harmed the US economy with particular reference to its GDP and unemployment levels since the onset of the GFC. We find, contrary to the commonly held belief, that China's foreign exchange policy has in fact helped the US recover from the GFC, albeit at the cost of strategic dependency on Chinese demand for its government debt.

\section{Background to China's Foreign Exchange Policy}

Like many developing nations, China maintains a managed, or pegged, currency exchange rate. Developing nations do so for several reasons including providing stability for trade and investment, allowing domestic infant industries to develop critical mass, and to acquire hard currency in its foreign reserves in preparation to enter a market-based arrangement 
at a later stage. China maintains a de facto crawling peg against the USD allowing its value to fluctuate within a very narrow band predetermined by the People's Bank of China.

Between 1994 and 2005, the exchange rate was fixed at close to 8.28 Yuan per USD. Reforms to the arrangements led the exchange rate to appreciate from 21 July 2005 until the process was halted in the midst of the GFC on 21 July 2008 when the exchange rate was held at close to 6.83 Yuan to the USD. From 19 June 2010, after the worst acute effects of the GFC had passed, the appreciation of the Yuan commenced once again.

What is relevant to this paper is the exchange rate is set at a level which results in a large bilateral trade deficit to the US with China. Furthermore, as China's currency peg is maintained through the use of a closed capital account, China's State Administration of Foreign Exchange acquires large volumes of foreign assets to balance capital flows. These are largely held in the form of US Treasury Bonds and GSE securities.

\section{Direct Influence of Chinese Demand for US Debt Assets}

China's policy to acquire high grade US debt can be considered as an exogenous upward shock to demand for these assets. As Borio \& Disyatat (2011) state, there need not be a direct, bilateral, financing link between countries that have trade imbalances although such imbalances must clear on a global basis. Nor does it follow that official reserves need necessarily be held in government issued debt or in the debt of government sponsored entities. Alternative reserve investment policy choices could readily have led to large portfolio investment in other assets like equities or gold. Morrison (2011) notes that US policymakers are openly concerned about a change in China's policy stance with respect to US debt instruments. This led to the introduction of bills in the $111^{\text {th }}$ Congress to increase transparency of foreign government holdings of US debt and better assess exposure to such risks. Consequently, we consider it a policy choice for the managers of China's foreign reserves to invest heavily in US Treasury and GSE debt. 
As the supply curve for debt assets is presumed to be unchanged due to this policy, and neither curve is perfectly elastic or inelastic in practice, standard supply-demand analysis suggests that the price of bonds and quantities issued will rise in equilibrium as a result of an upward shift of the demand curve.

As at 28 February 2011, China held approximately USD 1.2 trillion worth of US Treasury Bonds. This equates to approximately $12 \%$ of the total issuance of the bonds in public hands (source: CBO, author calculations). China was the largest foreign holder of these bonds (source: US Treasury). Additionally, China is estimated to hold approximately USD 500 billion of Government Sponsored Entity debt.

Gagnon, Raskin, Remache and Sack (2010) estimated the effect of the first of the more recent US efforts to monetise debt, which formed part of a USD 1.725 trillion expansion of the Fed balance sheet, was to reduce the yield on US 10 year bonds by between 38 and 82 basis points. As a result, China's foreign exchange policies, which resulted in large purchases of US government debt, have probably placed downward pressure on the yield for US debt securities and therefore produced an improvement on the terms under which the US Government was able to finance significant fiscal deficits in 2009 and 2010.

\section{The Impact on Trade}

The US is a capital rich economy with relatively high average wages. In contrast, China is a country in which capital is relatively scarce and wages are materially lower in comparison to its industrialised trade partners. As an indication of this, GNI per capita for China was USD 3,650 in 2009 (source: World Bank). The corresponding figure for the US was USD 46,360. While some commentators (for example, The Economist) highlight that Chinese wages and unit labour costs have accelerated since June 2009, low labour costs appear to remain an area of comparative advantage for China which continued to enjoy a substantial 
surplus of USD 15.8bn through 2010 in traded goods (source: China National Bureau of Statistics).

The Heckscher-Ohlin theorem suggests that trade patterns should reflect relative factor endowments. China has a relative abundance in labour and the US has substantive capital assets in place. The broad predictions of the model appear to hold empirically with China's main exports to the US being labour intensive goods like consumer electronics and apparel. In contrast, the US exports mainly capital goods like civilian aircraft and also other elaborately transformed manufactures (source: Bureau of Economic Analysis).

One important outcome is that the US imports disinflation from this trading partner. The rate of inflation on Chinese imported goods was $0.9 \%$ per annum for the two years to March 2011. This was materially below the figure of $3.4 \%$ for total imports, excluding fuels. This compares to the growth in the CPI experienced over the same period of $2.5 \%$ per annum or, excluding food and energy, 1.1\% (Source: Department of Labour).

By helping to keep inflation well anchored and within acceptable US monetary policy target bounds, China's policies provided flexibility to Fed officials as they pursued unconventional measures to stimulate the economy. However, significant wage escalation in China during 2011, impacting the cost of exports to the US, may disrupt this accommodation if not contained.

Having established that China's policies have contributed to lower inflation and interest rates in the US, we consider how these influences affected aggregate demand and employment.

\section{The Taylor Rule and GDP}

The Taylor Rule, used as a guide to monetary policy settings for central banks, provides a credible and useful rule of thumb linking recommended interest rates, inflation and GDP. Although there are several versions of the Taylor Rule, one of the simplest provides adequate insight for our purposes. It states: 


\section{Change in Interest Rate $=0.5 \times($ Actual Inflation Rate - Target Inflation Rate $)+$ \\ $0.5 \times$ (GDP Growth - Trend Measure of GDP Growth)}

The rule recommends easing monetary policy if inflation and output are below targeted levels. As previously discussed, China's policies place downward pressure on interest rates and actual inflation experience. It follows then, that China's policies provided an impetus and opportunity to close the output gap which had ballooned after the GFC.

In addition, it is noteworthy that the Fed Funds rate had fallen below $0.25 \%$ by April 2008 . The Fed had expanded its traditional open market operations to include acquiring GSE securities and mortgage backed securities by November 2008. These were further expanded from March 2009.

The Fed's quantitative easing program was undertaken to stimulate domestic capital formation and consumption, both of which boost GDP. As China's purchases of similar securities are a feature of their foreign exchange policy, their actions arguably contributed to improving US GDP.

\section{Okun's Law, GDP and Unemployment}

Okun's Law is an empirical observation that links GDP with changes in unemployment rates via an inverse relationship.

In the following chart, we show the inverse relationship between GDP and variation in unemployment rates in the US; both are seasonally adjusted. 


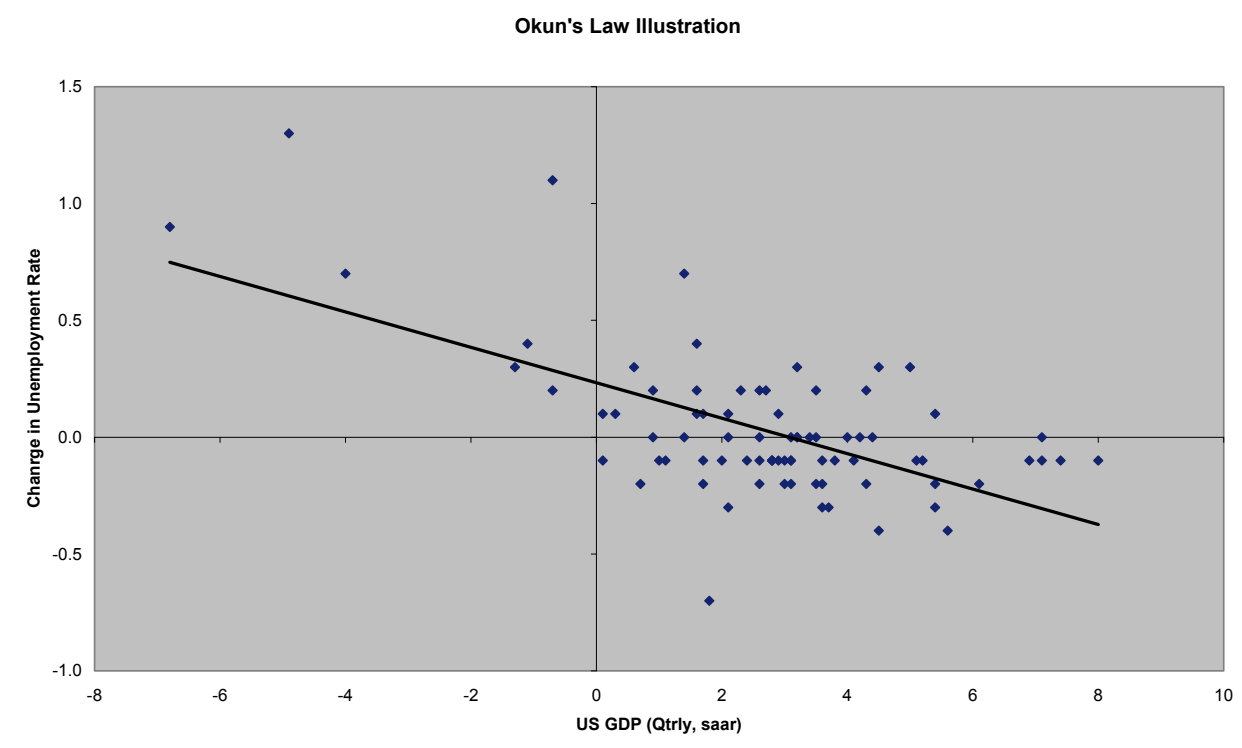

Source: FactSet, BEA, June 1991 to March 2011

We examined the correlation between the changes in GDP and unemployment with different lags between the two. The analysis highlights that causality appears to flow from GDP to change in unemployment: 
Correlogram: GDP Growth (Qtrly SAAR) vs Qtrly Change in Unemployment

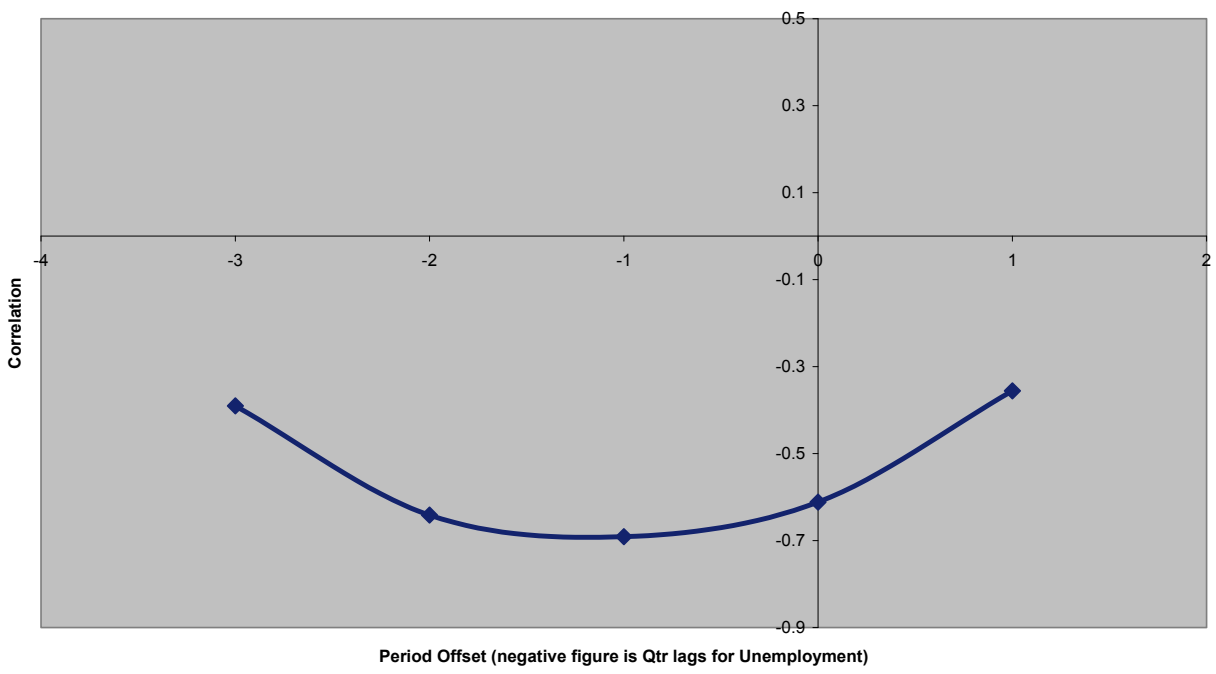

Source: FactSet, BEA, June 1991 to March 2011

By combining Okun's Law with the likely direction of causality, it appears that China's policies have also assisted with limiting the level of unemployment experienced in the US after the GFC.

\section{Potential Adverse Consequences of China's Foreign Exchange Policies for the US}

China's policies have left the US exposed to the possibility that a shift in targeted reserve composition could result in an adverse outcome. Reserve composition might alter following a change in the exchange rate regime itself or, more narrowly, via a change in China's reserve portfolio investment strategy.

Continued confidence in the performance of the US with respect to the ability and preparedness to honour its debt obligation is of vital importance to sustain the economic 
recovery efforts. Any sign from China that it has lost confidence in its holdings will be closely scrutinised. With the US Federal Government reporting annual fiscal deficits approximating $10 \%$ of GDP in recent years and an estimated government debt position of 69.4\% of GDP in 2011 (source: CBO, debt held in public hands), China has substantive ability to inflict harm on the US economy if it chose to, albeit not without cost to its own economic structure.

The US is vulnerable to China's ongoing appetite for US Treasury securities for its economic recovery. Nevertheless, in seeking to recover from the GFC, this support has been invaluable to the US and arguably to the entire set Western economies.

Some economists and policy makers believe that global trade and current account imbalances arising from China's policies contributed to the GFC. For example, Obstfeld and Rogoff (2009) found relationships between housing price changes and deterioration in current account balances for industrialised countries in the period preceding the GFC, providing grounds for supporting such beliefs.

Nonetheless, in the immediate period following the GFC, US monetary policy was targeted at containing a collapse in aggregate demand and towards taking steps to ensure that the supply of credit was not suddenly withdrawn. To that end, China's policies were instrumental in supporting the efforts of the US Federal Reserve and US Treasury.

From China's perspective, the policy makers face extraordinary challenges with managing the economic emergence of its populace. With the knowledge that "sudden stops" and runaway inflation have interrupted the economic prosperity of many emerging economies, it judges that sterilisation of flows and a managed currency via closed capital account are appropriate policy tools for the current stage of development.

The interventions cause certain imbalances in the economy, possibly producing a "savings glut" (Bernanke 2005). This reduces the cost of debt and a related search for yield phenomenon can create perverse incentives, leading to dislocations like the housing bubble. As such, China is often accused of contributing to the GFC itself. 


\section{Concluding Thoughts}

In the period following the GFC, China's demand for US issued Treasury bonds and ability to export disinflation to US consumers appears to have assisted a recovery in GDP and helped to limit the level of unemployment. The demand for US Treasury Bonds was also crucial in financing fiscal stimulus programs in 2009 and 2010.

In the longer term, the US appears to have grounds to seek to limit the extent to which it is reliant and beholden to China as a financier from a strategic perspective and, possibly, due to empirical associations between global imbalances and subsequent financial system instability.

Chinese officials believe that the costs of adjustment associated with a rapid appreciation of the Yuan would be high and contribute to domestic instability with global consequences. Additionally, some analysts observe a risk that Chinese policy reform would remove a large buyer of US debt from the market and offer no clear replacement.

It seems appropriate that progress towards reforming the currency policy should be undertaken in measured way.

\section{References}

- The Economist (2010) “Nominally cheap or really dear?" November 4, 2010

- Bernake, B (2005) “The Global Saving Glut and the US Current Account Deficit", Federal Reserve Board, Washington. 
- Borio, C and Disyatat, P (2011) "Global Imbalances and the Financial Crisis: Link or no link?", Bank for International Settlements, Switzerland.

- Gagnon, J; Raskin, M; Remache, J and Sack, B (2010) "Large-Scale Asset Purchases by the Federal Reserve: Did They Work?", Federal Reserve Bank of New York, New York.

- Morrison, WM (2011) "China-US Trade Issues", Congressional Research Service, Washington.

- Obstfeld, M and Rogoff, K (2009) "Global Imbalances and the Financial Crisis: Products of Common Causes", Federal Reserve Bank of San Francisco Asia Economic Policy Conference.

- Orphanides, A (2007) “Taylor Rules”, Federal Reserve Board, Washington 